\section{The Influence of 1-MCP on Shelf-Life Quality of Highbush Blueberry}

John M. DeLong ${ }^{1,3}$, Robert K. Prange ${ }^{1}$, Conny Bishop ${ }^{2}$, and Peter A. Harrison ${ }^{2}$

Agriculture and Agri-Food Canada, Atlantic Food and Horticulture Research Centre, 32 Main Street, Kentville, NS, Canada, B4N 1J5

Daniel A.J. Ryan ${ }^{1}$

Department of Mathematics and Computer Science, University of Prince Edward Island, 550 University Avenue, Charlottetown, Prince Edward Island, Canada, C1A 4P3

Additional index words. Vaccinium corymbosum, ethylene, shelf-life, storage

Abstract. To determine if postharvest treatments of 1-methylcyclopropene (1-MCP) retard the senescence of highbush blueberries (Vaccinium corymbosum $\mathrm{L}$.) removed from storage, 'Burlington' (early) and 'Coville' (late) fruit were harvested from four experimental sites and treated for 24 hours at $20^{\circ} \mathrm{C}$ with 0 (control), 25 (low), 100 (medium), or 400 (high) $\mathrm{nL} \cdot \mathrm{L}^{-1}$ of 1-MCP. All fruit were then stored in a controlled atmosphere of 10-15 $\mathrm{kPa} \mathrm{O}$ and $10 \mathrm{kPa} \mathrm{CO}$ at -1 to $1^{\circ} \mathrm{C}$ for 4,8 , and 12 weeks, followed by a $20{ }^{\circ} \mathrm{C}$ shelf-life of up to 20 days. During the shelf-life period immediately after harvest and those following each storage removal, percent marketable fruit (PMF) were calculated daily as: [fruit in good condition] $] /[$ total berry number $] \times 100$. Changes in PMF were not affected by 1 -MCP treatment; hence, we conclude that $1-\mathrm{MCP}$ at rates up to $400 \mathrm{~nL} \cdot \mathrm{L}^{-1}$ does not alter the shelf-life quality of the highbush blueberry cultivars tested.
Harvested highbush blueberries have a storage life of 2 or 3 weeks in $0^{\circ} \mathrm{C}$ refrigerated air or up to 5 or 6 weeks in a controlled atmosphere (CA) environment (Leyte and Forney, 1999; Pritts and Hancock, 1992). A longer storagelife duration, e.g., 8-12 weeks, would permit access to later season world markets that offer a premium for North American highbush blueberries when supply is usually low. Although blueberries do not generate large quantities of ethylene, the prevention of ethylene action may retard postharvest senescence, resulting in higher quality fruit. 1-Methylcyclopropene (1-MCP) has been shown to improve the postharvest and shelf-life quality of various fruits such as apples, pears, and kiwifruit by inhibiting ethylene-related senescence (Watkins and Miller, 2003). We hypothesized that postharvest 1-MCP treatment would retard the shelf-life senescence of CA-stored highbush

Received for publication 10 June 2002. Accepted for publication 16 Sept. 2002. Atlantic Food and Horticulture Research Centre contribution no. 2249. The authors thank Dr. D.M. Hodges and Dr. J. Song for reviewing this manuscript.

${ }^{1}$ Researcher.

${ }^{2}$ Technican

${ }^{3}$ To whom reprint requests should be sent; e-mail: DeLongJ@agr.gc.ca
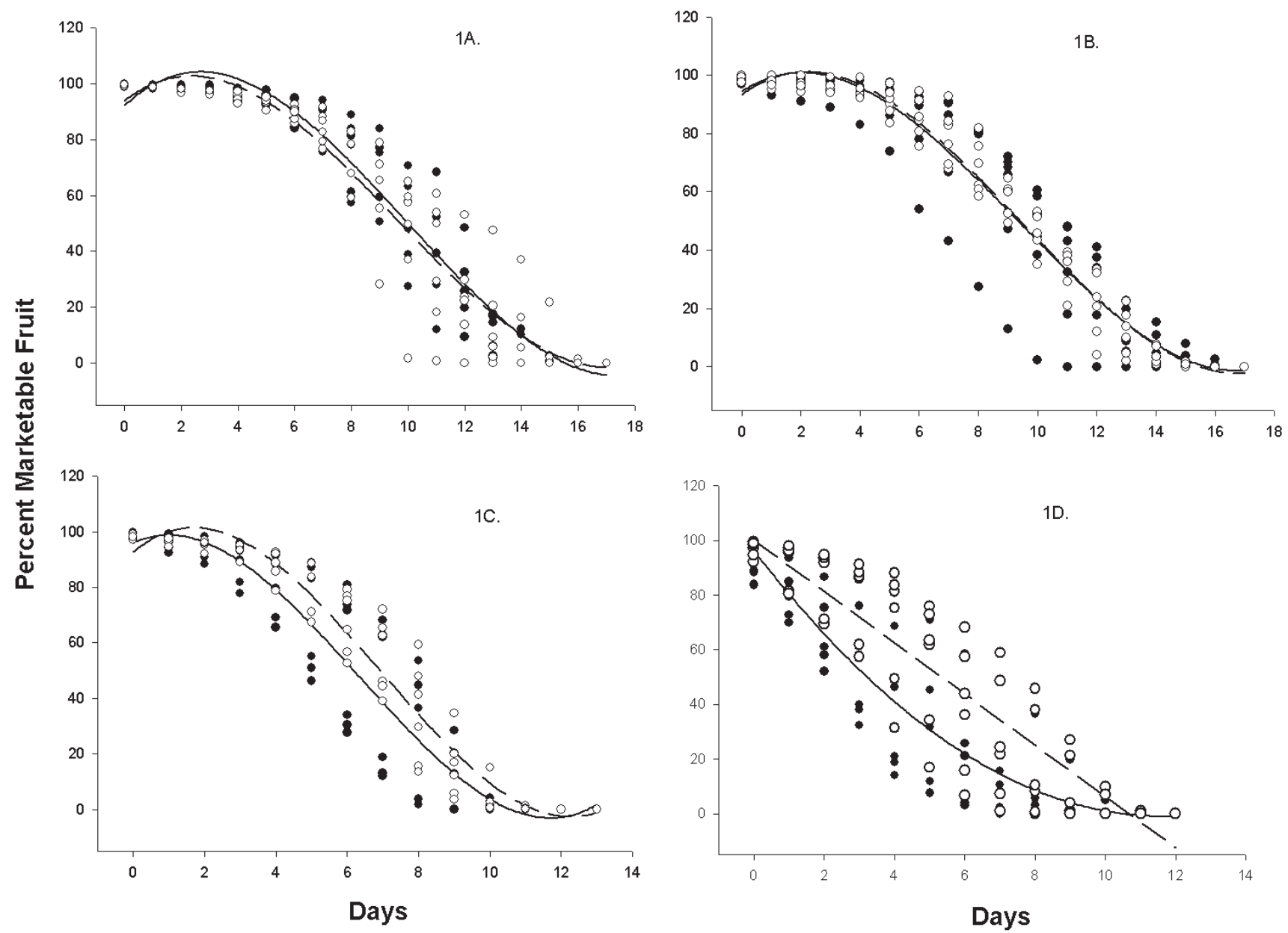

Fig. 1. Percent marketable 'Burlington' highbush blueberry fruit (Y) during a shelf-life period (X) following A) harvest, or CA storage of B) 4 , C) 8 , or D) 12 weeks. Regression equations for the Control (black circles, solid line) and $400 \mathrm{~nL} \cdot \mathrm{L}^{-1}$ (open circles, broken line) treatment data: A) Harvest, Control PMF: $92.2+9.52(\text { Day })^{1}-2.06(\text { Day })^{2}+0.07(\text { Day })^{3}, \mathrm{r}^{2}=0.95 ; 400 \mathrm{~nL} \cdot \mathrm{L}^{-1}$ PMF: $93.9+7.82(\text { Day })^{1}-1.90(\text { Day })^{2}+0.07(\text { Day })^{3}, \mathrm{r}^{2}=0.92 ;$ B) 4 Weeks, Control PMF: $94.5+6.58(\text { Day })^{1}-1.82\left(\right.$ Day $^{2}+0.07(\text { Day })^{3}, \mathrm{r}^{2}=0.91 ; 400 \mathrm{~nL} \cdot \mathrm{L}^{-1}$ PMF: $93.3+7.42(\text { Day })^{1}-1.91\left(\right.$ Day $^{2}+0.07(\text { Day })^{3}, \mathrm{r}^{2}=0.98 ;$ C) 8 Weeks, Control PMF: $96.0+5.76(\text { Day })^{1}-3.16(\text { Day })^{2}+0.17(\text { Day })^{3}, \mathrm{r}^{2}=0.90 ; 400 \mathrm{~nL} \cdot \mathrm{L}^{-1}$ PMF: $92.6+11.0(\text { Day })^{1}-3.70(\text { Day })^{2}+0.18(\text { Day })^{3}, \mathrm{r}^{2}=0.96$; D) 12 Weeks, Control PMF: $96.3-16.7(\text { Day })^{1}+0.72(\text { Day })^{2}, r^{2}=0.82 ; 400 n L^{-1} L^{-1}$ PMF: $100-9.38(\text { Day })^{1}+0.22(\text { Day })^{2}, r^{2}=0.84$. 

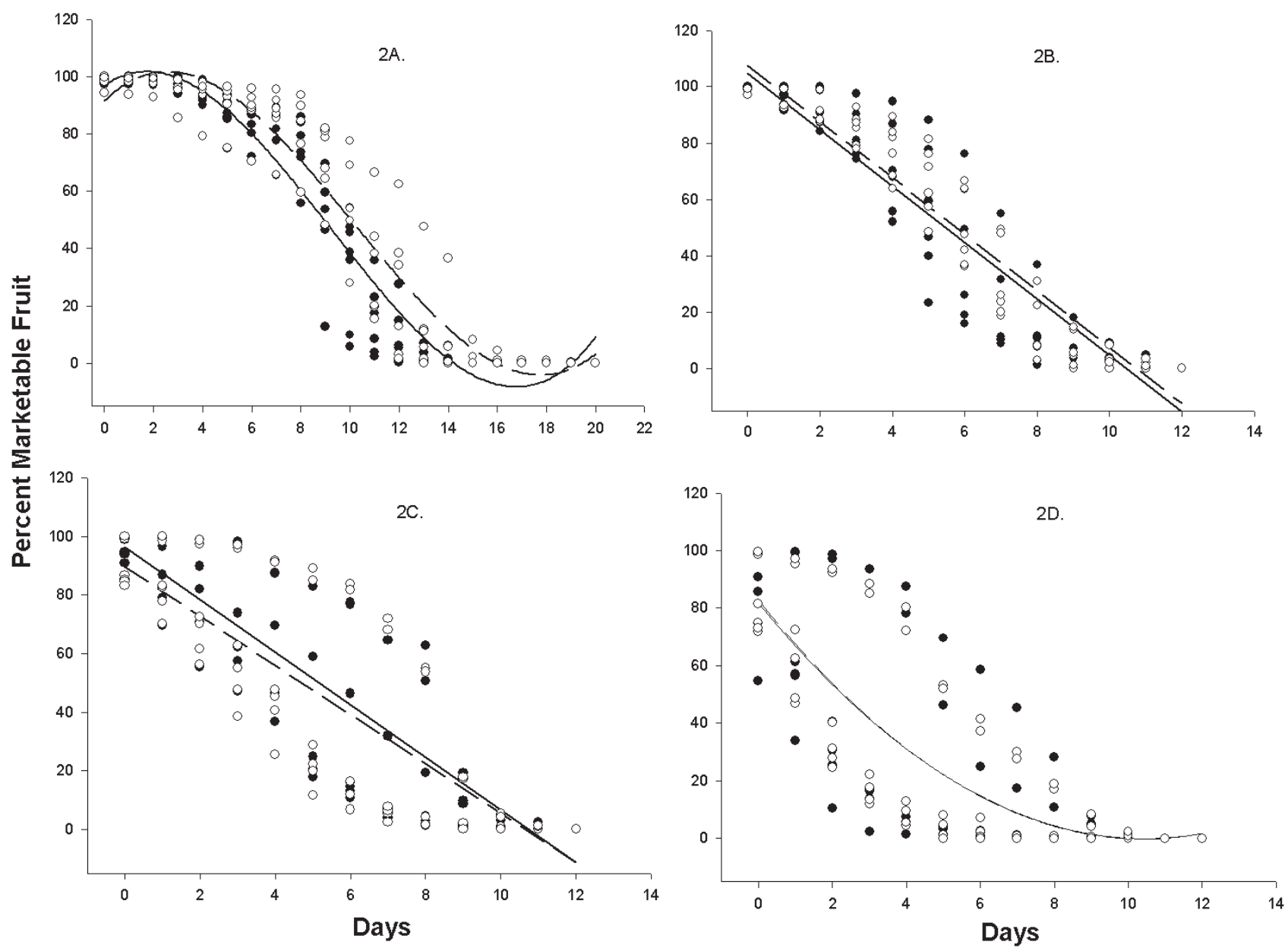

Fig. 2. Percent marketable 'Coville' highbush blueberry fruit (Y) during a shelf-life period (X) following A) harvest, or CA storage of B) 4 , C) 8 , or D) 12 weeks. Regression equations for the Control (black circles, solid line) and $400 \mathrm{~nL} \cdot \mathrm{L}^{-1}$ (open circles, broken line) treatment data: A) Harvest, Control PMF: $97.0+$ 5.62(Day) ${ }^{1}-1.79(\text { Day })^{2}+0.06(\text { Day })^{3}, \mathrm{r}^{2}=0.95 ; 400 \mathrm{~nL} \cdot \mathrm{L}^{-1}$ PMF: $91.6+8.22(\text { Day })^{1}-1.84(\text { Day })^{2}+0.06(\text { Day })^{3}, \mathrm{r}^{2}=0.93$; B) 4 Weeks, Control PMF: 104.7 - 10.0(Day) ${ }^{1} ; \mathrm{r}^{2}=0.87 ; 400 \mathrm{~nL} \cdot \mathrm{L}^{-1}$ PMF: $107.6-10.0$ (Day) ${ }^{1}, \mathrm{r}^{2}=0.92$; C) 8 Weeks, Control PMF: $96.4-8.98(\text { Day) })^{1}, \mathrm{r}^{2}=0.76 ; 400 \mathrm{~nL} \cdot \mathrm{L}^{-1}$ PMF: 89.6 - 8.41(Day) ${ }^{1}, \mathrm{r}^{2}=0.70$; D) 12 Weeks, Control PMF: 81.7 - 15.7(Day) ${ }^{1}+0.75(\text { Day })^{2}, \mathrm{r}^{2}=0.59 ; 400 \mathrm{~nL} \cdot \mathrm{L}^{-1}$ PMF: 82.8 $-16.0(\text { Day })^{1}+0.77(\text { Day })^{2}, \mathrm{r}^{2}=0.67$.

blueberries and thereby augment the quality of fruit following storage removal.

\section{Materials and Methods}

Four experimental sites were selected for 'Burlington' (early) and 'Coville' (late) highbush blueberries in the Annapolis Valley, Nova Scotia, Canada. Fruit were harvested from $\approx 15$ plants per site, after which four 1-MCP treatments (EthylBloc ${ }^{\circledR}$, BioTechnologies for Horticulture, Walterboro, S.C.; $0.14 \%$ active ingredient) - a) $0 \mathrm{~nL} \cdot \mathrm{L}^{-1}$ (control); b) $25 \mathrm{~nL} \cdot \mathrm{L}^{-1}$ (low); c) $100 \mathrm{~nL} \cdot \mathrm{L}^{-1}$ (medium); and d) 400 $\mathrm{nL} \cdot \mathrm{L}^{-1}$ (high) - were applied for $24 \mathrm{~h}$ at 20 ${ }^{\circ} \mathrm{C}$ prior to storage by mixing the appropriate quantity of dry powder with $\approx 22 \mathrm{~mL}$ of $\mathrm{H}_{2} \mathrm{O}$-based buffer in a $0.34-\mathrm{m}^{3}$ chamber. The fruit were then stored at $10-15 \mathrm{kPa} \mathrm{O}_{2}$ and 10 $\mathrm{kPaCO}_{2}$ at -1 to $1{ }^{\circ} \mathrm{C}$ for 4,8 , and 12 weeks, followed by a $20^{\circ} \mathrm{C}$ shelf-life of up to $20 \mathrm{~d}$. During each day of the shelf-life period, berries in good condition as well as shriveled, rotten, split, and deformed fruit were counted; percent marketable fruit (PMF) was then calculated as: [fruit in good condition]/[total berry number] $\times 100$. Potential treatment effects were associated with differences in the PMF curves over the shelf-life period. A shelf-life PMF assessment was also performed immediately following harvest.

\section{Results and Discussion}

In general, 1-MCP treatments did not alter the PMF during the shelf-life periods for either cultivar; hence, only the control and the high rates $\left(400 \mathrm{~nL} \cdot \mathrm{L}^{-1}\right)$ are presented (Figs. $1 \mathrm{~A}-\mathrm{D}$; 2A-D). Data were fitted to 2nd- or 3rd-order polynomial regression curves if the coefficient of simple variation $\left(\mathrm{r}^{2}\right)$ improved by at least $5 \%$ over the linear or 2 nd-order fit. Although the 12-week shelf-life data indicated that the high 1-MCP rate on the 'Burlington' fruit altered the rate of decline in PMF compared with the control berries (Fig. 1D), the effect was neither physiologically nor economically meaningful.

It is possible that higher 1-MCP application rates could elicit beneficial poststorage effects. The 1-MCPconcentrations used in this study were a compromise between product efficacies reported at the rates of $0.8-1.0 \mu \mathrm{L} \cdot \mathrm{L}^{-1}$ for apple (Fan et al., 1999) and 5-15 $\mathrm{nL} \cdot \mathrm{L}^{-1}$ for strawberry (Ku et al., 1999). If highbush blueberries are responsive to 1-MCP, the 16- fold difference between the low and the high application rates should have shown a consistent incremental response; none, however, was observed. In summary, 1-MCP at rates up to $400 \mathrm{~nL} \cdot \mathrm{L}^{-1}$ did not affect the shelf-life quality of two highbush blueberry cultivars following a CA storage regime spanning 12 weeks.

\section{Literature Cited}

Fan, X., S.M. Blankenship, and J.P. Mattheis. 1999. 1-Methylcyclopropene inhibits apple ripening. J. Amer. Soc. Hort. Sci.124:690-695.

Ku, V.V.V., R.B.H. Wills, and S. Ben-Yehoshua. 1999. 1-Methylcyclopropene can differentially affect the postharvest life of strawberries exposed to ethylene. HortScience 34:119-120.

Leyte, J.C. and C.F. Forney. 1999. Controlled atmosphere tents for storing fresh commodities in conventional refrigerated rooms. HortTechnology 9:672-675.

Pritts, M.P. and J.F. Hancock. 1992. Highbush blueberry production. Northeast Reg. Agr. Eng. Serv. (NRAES). Ser. 55, Ithaca, N.Y.

Watkins, C.B. and B. Miller. 2003. A summary of physiological processes or disorders in fruits, vegetables and ornamental products that are delayed or decreased, increased, or unaffected by application of 1-methylcyclopropene (1-MCP). http://www.hort.cornell.edu/department/faculty/ watkins/ethylene/index.htm. 